\title{
A NEW SPECIES OF THE GENUS HEMIRHOPALUM (COLEOPTERA, DERMESTIDAE) FROM BOLIVIA
}

\section{J. Háva}

Department of Forest Protection and Entomology, Faculty of Forestry and Wood Sciences, Czech University of Life Sciences, Kamýcká 1176, CZ-165 21, Prague 6 - Suchdol, Czech Republic E-mail: jh.dermestidae@volny.cz

\begin{abstract}
A New Species of the Genus Hemirhopalum (Coleoptera, Dermestidae) from Bolivia. Háva J. Hemirhopalum alleni Háva, sp. n. from Bolivia (South America) is described, illustrated and compared with two similar species: Hemirhopalum bicolor Sharp, 1902 and H. brasiliense Herrmann et Háva, 2013.

Key words: taxonomy, new species, Coleoptera, Dermestidae, Hemirhopalum, Megatominae, South America, Bolivia.

Новый вид рода Hemirhopalum (Coleoptera, Dermestidae) из Боливии. Гава И. - Описан Hemirhopalum alleni Háva, sp. n. из Боливии. Приведены его иллюстрации и сравнение с двумя сходными видами: Hemirhopalum bicolor Sharp, 1902 and H. brasiliense Herrmann et Háva, 2013.
\end{abstract}

Ключевы е слова: таксономия, новый вид, Coleoptera， Dermestidae, Hemirhopalum, Megatominae, Южная Америка, Боливия.

\section{Introduction}

The genus Hemirhopalum Sharp, 1902 belongs to the subfamily Megatominae, tribe Megatomini and currently includes 14 species worldwide. With two exceptions (Hemirhopalum rufipenne Pic, 1916 and Hemirhopalum hadrotomoide Sharp, 1902, both occurring in Mexico and North America) this genus is restricted to the Neotropical Region (Sharp 1902; Háva 2003, 2012; Herrmann, Háva 2013).

\section{Material and methods}

Results of measurements are presented by using the following abbreviations:

$\mathrm{EW}-$ elytral width $=$ maximum elytral width;

$\mathrm{TL}-$ total length $=$ distance from anterior margin of pronotum to apex of elytra

Other abbreviations:

JHAC Private Entomological Laboratory and Collection, Únětice u Prahy, Prague-west, Czech Republic; ALPC - Albert Allen private collection, Idaho, U. S. A;

NMNH - National Museum of Natural History, Washington D.C., U. S. A.

Hemirhopalum alleni Háva, sp. n. (fig. 1-3)

Type material. Holotype ơ: Bolivia: "Yuyu, Mapiri, La Paz, 10.viii.1989" (NMNH). Paratypes: 2 o: same label data (ALPC, JHAC). Each type specimen was additionally provided with a red label "Holotype [or Paratype, respectively], Hemirhopalum alleni sp. n., Jiří Háva det. 2013".

Description. Body measurements in $\mathrm{mm}$ : $\mathrm{TL}=3.9-4.1, \mathrm{EW}=2.1-2.2$. Body shiny black, oblong oval, maximum width posterior of its middle (fig. 1). Dorsal surface bare, apparently without any pubescence, but with extremely short single seta in each puncture hardly visible at very bright illumination under magnification $80 \times$ by using a stereoscopic microscope. Head as broad as long, densely and coarsely punctate between eyes and antennae, distances between punctures somewhat smaller than puncture diameter. Palpi light brown to yellow, ocellus present on front. Antennae with 11 antennomeres, light brown to yellow except first segment dark brown; antennal club 

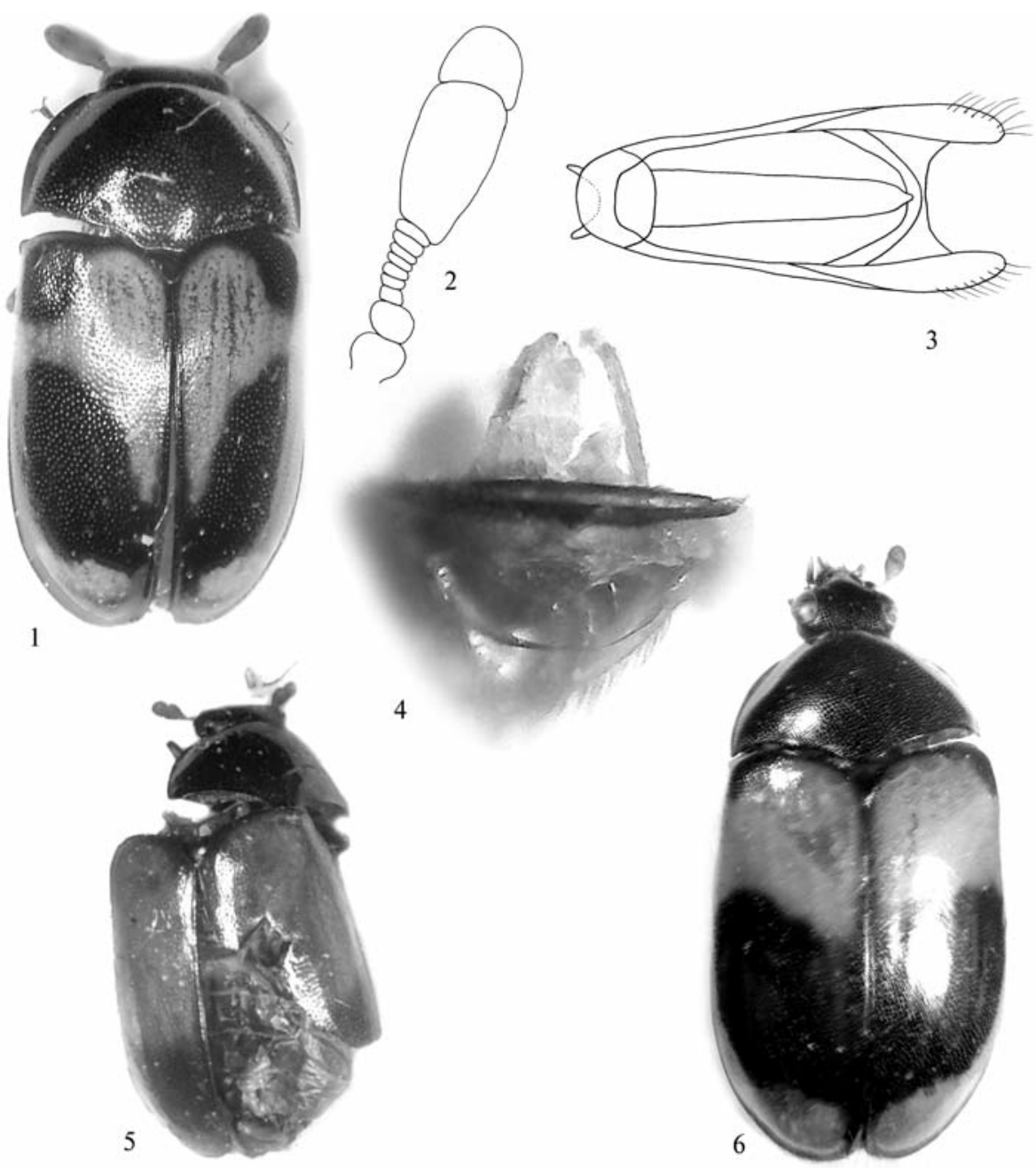

Fig. 1-6. Hemirhopalum alleni sp. n., holotypus (1-4), H. bicolor, holotype (5) and H. brasiliense, holotype (6): 1, 5, 6 - habitus, dorsal view; 2 - antenna of male; 3 - lateral apophyses of abdominal sternum 8; $4-$ aedeagus.

Рис. 1-6. Hemirhopalum alleni sp. п., голотип (1-4), H. bicolor, голотип (5) и H. brasiliense, голотип (6): 1, 5, 6 - общий вид, сверху; 2 - антенна самца; 3 - латеральный апофиз 8-го брюшного стернума; 4 - эдеагус.

consisting of 2 antennomeres, clearly distinct, ovate and much broader than other antennomeres, about twice as long as shaft, covered by hardly visible procumbent pubescence and a few solitary setae (fig. 2); first two segments of shaft with a few longer setae, too. Eyes quite big, with tiny ocelli, apparently without setae under magnification $80 \times$. Pronotum shiny black, quite densely and coarsely punctate (as head), almost twice as wide as long, narrowed anteriorly, broadest at its apical part, its distinct lateral margins completely visible from above; cuticle between punctuation shiny. Posterior angles almost rectangular, with rounded edge, completely visible from above; anterior angles obtusely angulate and also visible from above. Elytra with much finer punctuation compared to pronotum, space between punctures bigger than puncture diameter; cuticle shiny and entirely black, without notable pubescence; each elytron with two yellow fasciae. One fascia covering nearly whole anterior half except shoulder, other fascia in apical one-fifth of elytron. Scutellum small and somewhat triangular, shiny black, with punctures as on elytra. Punctation and colour of underside (mesoventrum, 
metaventrum and abdominal ventrites) similar to that of pronotum. Abdominal visible ventrites brown, punctures in the middle sparse and fine, but increasing strongly in density and roughness towards lateral margins. Each puncture (throughout whole underside) provided with single decumbent seta reaching to neighbouring puncture. Lateral apophyses of abdominal sternum 8 as in fig. 4. Legs somewhat flattened, entirely black, with punctures and setae as on abdomen and other parts of underside. Two basal tarsites of left mid leg brown (other tarsi entirely missing in specimens). Aedeagus as in fig. 3.

Diagnosis. The new species can be easily distinguished from the similar species Hemirhopalum bicolor Sharp, 1902, by the presence of two yellow fasciae on its elytra, whilst $H$. bicolor has only one fascia, which is located in the anterior part only (fig. 5); from H. brasiliense Herrmann et Háva, 2013 (fig. 6) by its yellow elytral fasciae and structure of antennae.

Distribution. Bolivia.

Etymology. The species name is patronymic, named for coleopterologist Albert Allen, Idaho, U.S.A.

I am indebted very much to Albert Allen for the loan of interesting dermestid material and to Miloslav Rakovič (Prague, Czech Republic) for revision of the English manuscript. This research was supported by the Internal Grant Agency (IGA n. 20124364), Faculty of Forestry and Wood Sciences, Czech University of Life Sciences Prague.

\section{References}

Háva J. World Catalogue of the Dermestidae (Coleoptera) // Studie a Zprávy Oblastního Muzea Prahavýchod v Brandýse nad Labem a Staré Boleslavi. - 2003. - Suppl. 1. - 196 p.

Háva J. Contribution to dermestid species (Coleoptera: Dermestidae) described by David Sharp from the Neotropical Region. Part 4 // Arquivos Entomolyxicos. - 2012. - N 7. - P. 155-158.

Herrmann A., Háva J. A new species of the genus Hemirhopalum Sharp, 1902 (Coleoptera: Dermestidae) from Brazil // Studies and Reports. Ser.Taxonomical. - 2013. - N 9 (1). - P. 61-64. - In press.

Sharp D. S. Dermestidae // Biologia Centrali-Americana. Insecta. Coleoptera / Eds F. Godman, O. Salvin. - Vol. 2, part 1. - London : Dulau and Co., 1902. - P. 642-669.

Received 21 March 2013

Accepted 20 May 2013 